\title{
DETERMINAN KEJADIAN BALITA BAWAH GARIS MERAH (BGM) DI WILAYAH KERJA PUSKESMAS MUMBULSARI KABUPATEN JEMBER
}

\author{
Dian Septiawati Endariadi, Farida Wahyu Ningtyias, Ninna Rohmawati \\ Bagian Gizi Kesehatan Masyarakat, Fakultas Kesehatan Masyarakat Universitas Jember \\ Jalan Kalimantan 37 Jember 68121 \\ Email: farida.fkm@unej.ac.id
}

\begin{abstract}
Toddler with the below red line is the weighting of the results of a children weight which are placed on the cards toward health below the red line. The Preliminary study that has been done that the number of BGM toddler at Mumbulsari Primary Health Care is 178 toddlers. This study aims to identify the determinants of Toddler with below red line incidents at work region Mumbulsari Primary Health Care Jember District. This research is a type of descriptive research. The sample in this study uses simple random sampling (63 BGM toddlers). The results of research conducted on mothers/caregivers of a toddler who covered the characteristics of a toddler were 41.3\% (12-24 months), $55.6 \%$ women, $71.4 \%$ not BBLR, maternal characteristics included maternal education $96.8 \%$ graduated from SD/MI/SMP/MTS, 76.2\% did not work, $79.4 \%$ had enough knowledge, family characteristics $98.4 \%$ worked, family income $98.4 \%$ (<UMK), family members $68.3 \%$ ( $\leq 4$ people). Parenting includes giving colostrum 76.2\%, 61.9\% exclusive breastfeeding, 55.6\% giving of MP-ASI. Sanitation and health services covering $92.1 \%$ hand washing, wash the cutlery and drink $74.6 \%$, $100 \%$ access to clean water wells, the source of drinking water wells use 93.7\%, 77.8\% complete immunization status, the Ministry of health visited midwife practice $79.4 \%$, easy service access reach out to $90.5 \%$. The level of food consumption is at a deficit level of weight with $85.7 \%$ of the amount of energy, protein $57,1 \%$, carbohydrates $93.7 \%$ and fat $74,6 \%$. No infection of $79.4 \%$.
\end{abstract}

Keywords: Determinants, Below Red Line, Toddler

\begin{abstract}
ABSTRAK
Balita Bawah Garis Merah (BGM) merupakan hasil penimbangan berat badan balita yang dititikkan dalam kartu menuju sehat (KMS) berada di bawah garis merah. Studi pendahuluan yang telah dilakukan bahwa jumlah balita BGM di Puskesmas Mumbulsari adalah 178 balita. Penelitian ini bertujuan untuk mengidentifikasi determinan kejadian balita bawah garis merah (BGM) di wilayah kerja Puskesmas Mumbulsari Kabupaten Jember. Penelitian ini merupakan jenis penelitian deskriptif. Sampel pada penelitian ini menggunakan Simple random sampling (63 balita BGM). Hasil penelitian yang telah dilakukan pada ibu/pengasuh balita yang meliputi karakteristik balita adalah 41,3\% (1224 bulan), 55,6\% perempuan, 71,4\% tidak BBLR, karakteristik ibu meliputi pendidikan ibu 96,8\% tamat SD/MI/SMP/MTS, 76,2\% tidak bekerja, 79,4\% pengetahuan cukup, karakteristik keluarga 98,4\% ayah bekerja, pendapatan keluarga 98,4\% (<UMK), jumlah anggota keluarga $68,3 \%$ ( $\leq 4$ jiwa). Pola asuh meliputi pemberian kolostrum $76,2 \%$, pemberian asi-ekslusif $61,9 \%$, pemberian MP-ASI secara tepat $55,6 \%$. Sanitasi dan yankes yang meliputi cuci tangan $92,1 \%$, cuci alat makan dan minum $74,6 \%$, akses air bersih $100 \%$ sumur, sumber air minum menggunakan sumur $93,7 \%$, status imunisasi
\end{abstract}


lengkap $77,8 \%$, pelayanan kesehatan mengunjungi praktek bidan $79,4 \%$, akses pelayanan mudah menjangkau 90,5\%. Tingkat konsumsi makanan berada pada defisit tingkat berat dengan jumlah energi $85,7 \%$, protein $57,1 \%$, karbohidrat $93,7 \%$, dan lemak 74,6\%. Tidak ada infeksi 79,4\%.

Kata kunci: Determinan, Balita, Bawah Garis Merah (BGM)

\section{PENDAHULUAN}

Balita Bawah Garis Merah atau sering disebut juga dengan Balita BGM adalah balita dengan berat badan dititikkan dalam kartu menuju sehat (KMS) berada dibawah garis merah $^{1}$. Berat badan balita yang berada di bawah garis merah (BGM) merupakan suatu bentuk peringatan sebagai konfirmasi dan tindak lanjut balita yang mengalami kurang gizi. Badan kesehatan dunia (WHO) memperkirakan kurang gizi merupakan penyebab kematian anak dengan persentase $54 \%$ dan nantinya akan berlanjut ke gizi buruk. Indonesia memperkirakan 80\% kematian anak disebabkan oleh masalah gizi terutama gizi buruk ${ }^{2}$. Masalah gizi dikenal sebagai masalah multikompleks karena terdapat keterkaitan antara faktor satu dengan yang lain seperti halnya asupan makan dan penyakit infeksi. Makanan mempunyai peran yang sangat penting bagi tubuh untuk memelihara organ tubuh, pertumbuhan dan perkembangan otak serta untuk menjamin kelangsungan hidup manusia. Terdapat dua faktor yang dapat menyebabkan balita bawah garis merah (BGM) yaitu penyebab langsung dan tidak langsung. Penyebab langsung meliputi penyakit infeksi dan tingkat konsumsi. Tingkat konsumsi ditentukan oleh kualitas dan kuantitas suatu hidangan. Zat gizi yang dibutuhkan tubuh yang terkandung dalam suatu hidangan merupakan kualitas hidangan sedangkan kwantum masingmasing zat gizi yang dibutuhkan tubuh merupakan kuantitas suatu hidangan ${ }^{3}$. Menurut Soekirman dalam Made et al menyebutkan bahwa ketidaksesuaian tingkat konsumsi yang dibutuhkan tubuh menyebabkan tingginya angka gizi kurang secara langsung sedangkan pola asuh ibu terhadap anak akan pemberian asupan gizi merupakan faktor secara tidak langsung ${ }^{4}$. Hal ini juga didukung oleh Hasdianah \& Peristyowati dalam penelitiannya menjelaskan bahwa asupan makanan yang dikonsumsi secara baik dan benar sesuai dengan gizi seimbang mengandung zat gizi makro dan mikro yang berguna untuk tubuh ${ }^{5}$.

Survei yang dilakukan Dinas Kesehatan (Dinkes) Provinsi Jatim tahun 2015, menyebutkan bahwa terdapat $17,8 \%$ balita mengalami gizi kurang dengan batas minimal nasional angka balita gizi kurang $15,5 \%{ }^{6}$. Jawa Timur masuk kategori kritis untuk berat badan di bawah garis merah (BGM) dalam kartu menuju sehat (KMS), tercatat 1750 balita masuk kategori BGM yang menjadi fokus perhatian pemerintah dari 8000 balita $^{7}$. 
Laporan data BGM pada tahun 2017, Puskesmas Mumbulsari merupakan peringkat kedua untuk balita BGM tertinggi yang selalu mengalami kenaikan jumlah balita BGM di setiap tahunnya secara berturut-turut, dari tahun 2015 sampai 2017 yaitu dari 123 balita BGM di tahun 2015, 134 balita BGM di tahun 2016 dan 158 balita BGM di tahun $2017^{8}$. Studi pendahuluan yang dilakukan di Puskesmas Mumbulsari pada bulan februari 2018 telah mengalami peningkatan yaitu pada tahun 2017 sebanyak 158 balita BGM sampai bulan februari 2018 menjadi sebanyak 170 balita BGM. Oleh sebab itu, penulis tertarik untuk meneliti terkait "determinan kejadian balita BGM di wilayah kerja Puskesmas Mumbulsari Kabupaten Jember.

\section{METODE PENELITIAN}

Penelitian ini merupakan jenis penelitian deskriptif. Sampel pada penelitian ini menggunakan simple random sampling dengan jumlah 63 responden (ibu/pengasuh balita BGM). Penelitian ini dilakukan di wilayah kerja Puskesmas Mumbulsari Kabupaten Jember. Penelitian dilaksanakan pada bulan Februari 2018 sampai Agustus 2018. Variabel yang digunakan pada penelitian ini adalah karakteristik balita (umur, jenis kelamin dan status BBLR), karakteristik ibu dan keluarga (pendidikan ibu, pengetahuan ibu, pekerjaan ibu, pendapatan keluarga dan jumlah keluarga), pola asuh (pemberian kolostrum, pemberian ASI
Ekslusif, pemberian MP-ASI), sanitasi dan yankes (cuci tangan pakai sabun dan air mengalir, kebersihan peralatan makan balita, akses air bersih, sumber air minum, status imunisasi, sarana dan akses yankes), tingkat konsumsi makanan (energi, karbohidrat, protein dan lemak), dan riwayat penyakit infeksi.

\section{HASIL DAN PEMBAHASAN}

\section{Hasil Penelitian}

\section{Karakteristik Balita}

Tabel 1. Distribusi Karakteristik Balita BGM di wilayah kerja Puskesmas Mumbulsari

\begin{tabular}{lcr}
\hline \multicolumn{1}{c}{ Variabel } & $\mathrm{n}$ & $\%$ \\
\hline Umur & & \\
12-24 bulan & 26 & 41,3 \\
25-36 bulan & 19 & 30,2 \\
37-48 bulan & 14 & 22,2 \\
49-59 bulan & 4 & 6,3 \\
\hline Total & 63 & 100,0 \\
\hline Jenis Kelamin & & \\
Laki-laki & 28 & 44,4 \\
Perempuan & 35 & 55,6 \\
\hline Total & 63 & 100,0 \\
\hline Status BBLR & & \\
BBLR & 18 & 28,6 \\
Tidak BBLR & 45 & 71,4 \\
\hline Total & 63 & 100,0 \\
\hline
\end{tabular}

Berdasarkan Tabel diatas dapat diketahui bahwa mayoritas balita BGM terletak dalam rentang umur 12-24 bulan yaitu sebesar 41,3\% (26 balita) dan berjenis kelamin perempuan yaitu sebesar 55,6\% (35 balita), sedangkan untuk status BBLR, mayoritas tidak BBLR sebanyak 71,4\% (45 balita). 


\section{Karakteristik Ibu dan Keluarga Balita}

Tabel 2. Distribusi Karakteristik Ibu dan Keluarga balita BGM di wilayah kerja Puskesmas Mumbulsari

\begin{tabular}{lcr}
\hline \multicolumn{1}{c}{ Variabel } & $\mathrm{n}$ & \multicolumn{1}{c}{$\%$} \\
\hline Tingkat Pendidikan Ibu & & \\
SD/MI/SMP/MTS & 61 & 96,8 \\
SMA/MA/SMK & 2 & 3,2 \\
\hline Total & 63 & 100,0 \\
\hline Tingkat Pengetahuan Ibu & & \\
Pengetahuan Baik & 13 & 20,6 \\
Pengetahuan Cukup & 50 & 79,4 \\
\hline Total & 63 & 100,0 \\
\hline Status Pekerjaan Ibu & & \\
Bekerja & 15 & 23,8 \\
Tidak Bekerja & 48 & 76,2 \\
\hline Total & 63 & 100,0 \\
\hline Status Pekerjaan Ayah & & \\
Bekerja & 62 & 98,4 \\
Tidak Bekerja & 1 & 1,6 \\
\hline Total & 48 & 100,0 \\
\hline Pendapatan Keluarga & & \\
< UMK & 62 & 98,4 \\
$\geq$ UMK & 1 & 1,6 \\
\hline Total & 63 & 100,0 \\
\hline Jumlah Anggota Keluarga & & \\
< 4 Jiwa & 43 & 68,3 \\
5-7 Jiwa & 19 & 30,2 \\
> jiwa & 1 & 1,6 \\
\hline Total & 63 & 100,0 \\
\hline
\end{tabular}

Berdasarkan Tabel diatas sebagian besar ibu dari anak balita BGM mempunyai pendidikan SD/MI/SMP/MTS sebanyak 96,8\% (61 orang) dengan tingkat pengetahuan cukup sebesar 79,4\% (50 Orang). Status pekerjaan ibu, sebagian besar tidak bekerja sebanyak $76,2 \%$ (48 Orang). Sedangkan untuk status pekerjaan ayah sebagian besar bekerja dengan jumlah 98,4 $\%$ (62 orang). Pendapatan keseluruhan ayah dan ibu/keluarga sebagian besar <UMK yaitu sebesar 98,4\% (62 orang). Berdasarkan jumlah anggota keluarga, sebagian besar responden memiliki jumlah anggota keluarga $\leq 4$ Jiwa, yaitu $68,3 \%$ (43 orang).

\section{Pola Asuh Gizi Balita}

Tabel 3. Distribusi Pola Asuh gizi balita BGM di wilayah kerja Puskesmas Mumbulsari

\begin{tabular}{lrr}
\hline \multicolumn{1}{c}{ Variabel } & $\mathrm{n}$ & \multicolumn{1}{c}{$\%$} \\
\hline Pemberian Kolostrum & & \\
Ya & 48 & 76,2 \\
Tidak & 15 & 23,8 \\
\hline Total & 63 & 100,0 \\
\hline Pemberian ASI Ekslusif & & \\
Ya & 41 & 65,1 \\
Tidak & 22 & 34,9 \\
\hline Total & 63 & 100,0 \\
\hline Usia Pemberian MP-ASI & & \\
$\geq 6$ bulan & 41 & 65,1 \\
< 6 bulan & 22 & 34,9 \\
\hline Total & 63 & 100,0 \\
\hline Jenis MP-ASI & & \\
Sesuai & 52 & 82,5 \\
Tidak Sesuai & 11 & 17,5 \\
\hline Total & 63 & 100,0 \\
\hline Frekuensi MP-ASI & & \\
Sesuai & 47 & 74,6 \\
Tidak Sesuai & 16 & 25,4 \\
\hline Total & 63 & 100,0 \\
\hline
\end{tabular}

Berdasarkan Tabel diatas diketahui bahwa $76,2 \%$ (48 responden) memberikan kolostrum pada anaknya dan pemberian ASI Ekslusif sebanyak $61,9 \%$ (41 orang).

\section{Pemberian MP-ASI}

Tabel 4. Distribusi Pemberian MP-ASI balita BGM di wilayah kerja Puskesmas Mumbulsari

\begin{tabular}{llr}
\hline \multicolumn{1}{c}{ Variabel } & $\mathrm{n}$ & $\%$ \\
\hline Pemberian MP-ASI & & \\
Tepat & 35 & 55,6 \\
Tidak Tepat & 28 & 44,4 \\
\hline Total & 63 & 100,0 \\
\hline
\end{tabular}


Pemberian MP-ASI yang tepat sebanyak $55,6 \%$ (35 orang). Hal ini dinilai dari ketepatan dalam usia pemberian MP-ASI, Jenis pemberian MP-ASI dan frekuensi pemberian MP-ASI. Sedangkan persentase dari usia pemberian MPASI sendiri yang sesuai sebanyak $65,1 \%$ (41 orang), Jenis MP-ASI yang sesuai sebanyak $82,5 \%$ (52 orang) dan frekuensi pemberian MPASI sebanyak 74,6\% (47 orang).

\section{Sanitasi dan Pelayanan Kesehatan Balita}

Tabel 5. Distribusi Sanitasi di wilayah kerja Puskesmas Mumbulsari

\begin{tabular}{lcr}
\hline \multicolumn{1}{c}{ Variabel } & $\mathrm{n}$ & \multicolumn{1}{c}{$\%$} \\
\hline Mencuci Tangan dengan sabun & & \\
dan air mengalir & & \\
Ya & 5 & 7,9 \\
Tidak & 58 & 92,1 \\
\hline Total & 63 & 100,0 \\
\hline Kebersihan alat makan dan & & \\
minum balita & & \\
Ya & 16 & 25,4 \\
Tidak & 47 & 74,6 \\
\hline Total & 63 & 100,0 \\
\hline Akses air bersih & & \\
Sumur & 63 & 63,0 \\
PDAM & 0 & 0 \\
Sungai & 0 & 0 \\
Mata air & 0 & 0 \\
\hline Total & 63 & 100,0 \\
\hline Sumber air minum & & \\
Sumur & 59 & 93,7 \\
PDAM & 0 & 0 \\
Mata air & 0 & 0 \\
Air minum kemasan & 0 & 0 \\
Air minum isi ulang & 4 & 6,3 \\
\hline Total & 63 & 100,0 \\
\hline & & \\
\hline & &
\end{tabular}

Berdasarkan Tabel diatas diketahui bahwa persentase mencuci tangan dengan sabun dan air mengalir hanya sebesar $7,9 \%$ (5 orang), hal tersebut menyatakan bahwa lebih banyak responden melakukan cuci tangan dengan air mengalir saja dan persentasenya sebesar $92,1 \%$ (58 orang). Sedangkan untuk kebersihan alat makan dan minum, persentase paling banyak adalah responden yang tidak mencuci alat makan dengan air mengalir yaitu sebanyak $74,6 \%$ (47 orang). Untuk akses air bersih seluruh responden menggunakan sumur dan di setiap rumah responden dalam penelitian sudah terdapat sumur. Sumber air minum responden menggunakan air sumur dengan persentase sebesar $93,7 \%$ (59 orang).

Tabel 6 Distribusi Pelayanan Kesehatan balita BGM di wilayah kerja Puskesmas Mumbulsari

\begin{tabular}{lcr}
\hline \multicolumn{1}{c}{ Variabel } & $\mathrm{n}$ & \multicolumn{1}{c}{$\%$} \\
\hline $\begin{array}{l}\text { Status Imunisasi } \\
\text { Lengkap (HB0, BCG, }\end{array}$ & 49 & 77,8 \\
$\begin{array}{l}\text { DPT, Polio, Campak) } \\
\text { Tidak Lengkap }\end{array}$ & 14 & 22,2 \\
\hline Total & 63 & 100,0 \\
\hline Sarana Pelayanan & & \\
Kesehatan & & \\
Rumah sakit pemerintah & 0 & 0 \\
Rumah sakit swasta & 0 & 0 \\
Puskesmas/pustu & 11 & 17,5 \\
Praktek dokter/klinik & 2 & 3,2 \\
$\begin{array}{l}\text { Praktek bidan/rumah } \\
\text { bersalin }\end{array}$ & 50 & 79,4 \\
$\begin{array}{l}\text { Poskesdes/poskestren } \\
\text { Polindes }\end{array}$ & 0 & 0 \\
\hline Total & 0 & 0 \\
\hline Akses Pelayanan & 63 & 100,0 \\
$\begin{array}{l}\text { Kesehatan } \\
\text { Sulit menjangkau }\end{array}$ & & \\
Cukup mudah & 0 & 0 \\
menjangkau & 6 & 9,5 \\
Mudah menjangkau & 57 & 90,5 \\
\hline Total & 63 & 100,0 \\
\hline
\end{tabular}


Berdasarkan Tabel 6, diketahui sebagian besar responden yang sering mengunjungi sarana pelayanan kesehatan dengan tujuan pengobatan adalah praktek bidan/Rumah bersalin, yaitu sebesar 79,4\%. Berdasarkan akses pelayanan kesehatan, umumnya responden mudah menjangkau, yaitu sebesar 90,5\%. Status imunisasi balita BGM sebagian besar sudah lengkap dengan persentase $77,8 \%$.

\section{Tingkat Konsumsi Makanan Balita}

Tabel 7. Distribusi Tingkat Konsumsi Makanan balita BGM di wilayah kerja Puskesmas Mumbulsari

\begin{tabular}{lcr}
\hline \multicolumn{1}{c}{ Variabel } & $\mathrm{n}$ & \multicolumn{1}{c}{$\%$} \\
\hline Energi & 54 & 85,7 \\
Defisit Tingkat Berat & 9 & 14,3 \\
Defisit Tingkat Sedang & 0 & 0 \\
Defisit Tingkat Ringan & 0 & 0 \\
Normal & 0 & 0 \\
Lebih & 63 & 100 \\
\hline Total & & \\
\hline Karbohidrat & 59 & 93,7 \\
Defisit Tingkat Berat & 4 & 6,3 \\
Defisit Tingkat Sedang & 0 & 0 \\
Defisit Tingkat Ringan & 0 & 0 \\
Normal & 0 & 0 \\
Lebih & 63 & 100 \\
\hline Total & & \\
\hline Protein & 36 & 57,1 \\
Defisit Tingkat Berat & 23 & 36,5 \\
Defisit Tingkat Sedang & 4 & 6,3 \\
Defisit Tingkat Ringan & 0 & 0 \\
Normal & 0 & 0 \\
Lebih & 63 & 100 \\
\hline Total & & \\
\hline Lemak & 47 & 74,6 \\
Defisit Tingkat Berat & 15 & 23,8 \\
Defisit Tingkat Sedang & 1 & 1,6 \\
Defisit Tingkat Ringan & 0 & 0 \\
Normal & 0 & 0 \\
Lebih & & 100 \\
\hline Total & \\
\hline
\end{tabular}

Berdasarkan pada Tabel diatas menunjukkan bahwa tingkat konsumsi energi, karbohidrat, protein dan lemak pada balita BGM sebagian besar berada pada defisit tingkat berat yaitu pada energi sebesar $85,7 \%$ (54 balita) dengan ratarata asupan energi sebesar 489,25 kkal, karbohidrat 93,7\% (59 balita) dengan rata-rata asupan karbohidrat sebesar 55,80 g, protein sebesar 57,1\% (36 balita) dengan rata-rata konsumsi protein sebesar 17,99 g, dan lemak sebesar $74,6 \%$ (47 balita) dengan rata-rata konsumsi lemak sebesar 26,56 g.

\section{Riwayat Penyakit Infeksi Balita}

Tabel 8. Distribusi Riwayat Penyakit Infeksi balita BGM di wilayah kerja Puskesmas Mumbulsari

\begin{tabular}{lcc}
\hline Penyakit Infeksi & $\mathrm{n}$ & $\%$ \\
\hline Ada & 13 & 20,6 \\
Tidak & 50 & 79,4 \\
\hline Total & 63 & 100,0 \\
\hline
\end{tabular}

Berdasarkan pada Tabel diatas menunjukkan bahwa riwayat penyakit infeksi pada anak balita BGM sebagian besar menunjukkan tidak ada penyakit infeksi yang diderita selama 3 bulan terakhir, hal tersebut ditunjukkan dengan persentase sebesar 79,4\% (50 orang).

\section{Pembahasan}

\section{Karakteristik Balita BGM}

\section{Usia balita BGM}

Usia balita terutama 12-36 bulan merupakan masa pertumbuhan yang cepat sehingga memerlukan kebutuhan gizi yang paling banyak dibandingkan dengan masa-masa 
selanjutnya ${ }^{9}$. Hasil penelitian ini mayoritas usia balita BGM terdapat dalam rentang usia 12-24 bulan, hal tersebut dikarenakan sebagian ibu yang bekerja dan anak dititipkan pada nenek ataupun anggota keluarga sehingga ibu tidak mengetahui kebiasaan balitanya jika sedang bekerja, selain itu pada usia tersebut anak juga belum mampu meminta ataupun memilih makanan yang diinginkannya. Hasil penelitian Rosela et al mengatakan bahwa anak yang mengalami perkembangan yang tidak tercapai yaitu pada usia 12-24 bulan dikarenakan di asuh oleh nenek/pengasuhnya karena orang tua mereka yang sibuk bekerja sehingga kebutuhan dasar balita tersebut tidak terpenuhi sepenuhnya ${ }^{10}$.

\section{Jenis kelamin}

Jenis kelamin merupakan salah satu faktor penentu kebutuhan zat gizi jika dilihat dari aktivitas fisik. Kebutuhan zat gizi berbeda antara laki-laki dan perempuan. Anak laki-laki lebih banyak melakukan aktivitas fisik sehingga memerlukan energi yang lebih banyak dibanding perempuan ${ }^{11}$. Penelitian ini mayoritas balita BGM berjenis kelamin perempuan.

Menurut penelitian Novitasari, jenis kelamin perempuan paling banyak mengalami gizi buruk karena dalam kehidupan sehari-hari masih banyak keluarga yang memberikan porsi lebih banyak kepada laki-laki daripada perempuan dan mengutamakan pemberian makanan terlebih dahulu pada laki-laki setelah itu perempuan ${ }^{9}$.

\section{Status BBLR}

BBLR merupakan salah satu faktor kejadian BGM, pada BBLR zat antibodi kurang sempurna sehingga lebih mudah terkena penyakit, penyakit ini menyebabkan balita kurang nafsu makan sehingga asupan makanan yang masuk ke dalam tubuh menjadi berkurang dan dapat menyebabkan balita tersebut mengalami $\mathrm{BGM}^{9}$. Hasil penelitian ini menunjukkan bahwa mayoritas balita tidak BBLR. Penelitian Patandianan et al menyatakan bahwa tidak terdapat hubungan yang bermakna dari berat lahir dengan status gizi namun terdapat korelasi positif yang artinya semakin besar nilai berat lahir semakin besar pula nilai status gizi ${ }^{12}$.

\section{Karakteristik Ibu dan Keluarga}

1. Tingkat Pendidikan ibu

Tingkat pendidikan menentukan mudah tidaknya seseorang menyerap dan memahami pengetahuan gizi yang di dapat, sehingga hal ini bisa dijadikan landasan untuk membedakan metode penyuluhan yang tepat. Hasil penelitian ini mayoritas ibu mempunyai tingkat pendidikan SD/MI/SMP/MTS. Seorang ibu dengan tingkat pendidikan yang tinggi akan merencanakan menu makanan yang sehat dan bergizi bagi anak-anaknya. Hal ini sejalan dengan penelitian Damanik et al yang menyatakan bahwa pendidikan ibu mempunyai peranan penting dalam mencegah terjadinya masalah underweight pada balita, seorang ibu juga dapat menentukan bagaimana pola asuh yang akan 
dipilihnya terutama dalam pemilihan makanan untuk balitanya ${ }^{13}$.

2. Tingkat Pengetahuan Ibu

Pengetahuan yaitu pembentukan yang secara terus-menerus dialami oleh seseorang yang setiap saat mengalami penyusunan kembali karena adanya pemahaman baru. Hasil penelitian ini menunjukkan bahwa tingkat pengetahuan ibu dalam kategori cukup, akan tetapi ibu tidak menerapkan dalam kehidupan sehari-hari sehingga gizi anak tidak terpantau sepenuhnya oleh ibu. Hal ini sejalan dengan penelitian Khotimah dan Kuswandi salah satu penyebab gangguan gizi adalah kurangnya pengetahuan gizi atau kemampuan untuk menerapkan informasi tentang gizi dalam kehidupan sehari-hari, sehingga hal tersebut dapat mempengaruhi status gizi balita yang pada akhirnya balita akan mengalami gizi kurang akibat tidak mampunya ibu dalam menerapkan informasi tentang gizi ${ }^{14}$.

3. Status Pekerjaan Ibu dan Ayah

Berdasarkan hasil penelitian ini terdapat 15 responden ibu yang bekerja akan tetapi pekerjaannya hanya separuh waktu saja sebagai buruh tani. Sedangkan untuk pekerjaan ayah sebagian besar bekerja sebagai buruh tani dan buruh bangunan.

Menurut penelitian Labada et al ibu dengan bekerja berisiko 1.667 kali lebih besar mempunyai anak dengan status gizi tidak normal (gizi buruk, gizi kurang dan gizi lebih) dibandingkan ibu yang tidak bekerja ${ }^{15}$.

\section{Pendapatan Keluarga}

Hasil penelitian ini menunjukkan bahwa sebagian besar responden mempunyai pendapatan yang kurang yaitu sebanyak 62 responden. Persulessy et al dalam penelitiannya menyebutkan bahwa pendapatan keluarga terkait dengan pembelian dan pemilihan bahan makanan sehingga anak yang tidak cukup makan, daya tahan tubuhnya melemah dan dengan keadaan yang demikian anak mudah diserang infeksi, kurang nafsu makan dan akhirnya rentan terhadap kurang gizi ${ }^{16}$.

5. Jumlah Anggota Keluarga

Hasil penelitian ini menunjukkan bahwa responden sebagian besar memiliki jumlah keluarga $\leq 4$ orang. Nurapriyanti menyebutkan bahwa ada pengaruh antara jumlah anggota keluarga dengan status gizi. Jumlah anggota keluarga akan mempengaruhi pada alokasi pendapatan keluarga dalam memenuhi kebutuhan pangannya ${ }^{17}$.

\section{Pola Asuh Gizi}

\section{Pemberian Kolostrum}

Hasil penelitian yang telah dilakukan terdapat 15 balita yang tidak mendapatkan kolostrum dikarenakan ibu yang melahirkan di rumah sakit dan bayi langsung dibawa ke ruang bayi dan ada juga beberapa ibu yang lahirnya di dukun jadi tidak ada asuhan untuk bayinya. Menurut Yafelli dan Muqsith bayi yang tidak memiliki riwayat pemberian kolostrum akan mengalami gangguan tumbuh kembang dan tidak mampu mencukupi kebutuhan dasar 
seperti nutrisi dan imunisasi karena kandungan yang berada dalam kolostrum sangat bermanfaat untuk tumbuh kembang balita, sehingga nantinya balita memiliki tingkat imunitas yang rendah dan akan mudah terserang penyakit infeksi. Keadaaan seperti ini yang mengakibatkan balita rentan terhadap kurang gizi yang nantinya akan mengarah ke berat badan balita dibawah garis merah ${ }^{18}$.

\section{Pemberian Asi Ekslusif}

Hasil penelitian yang telah dilakukan sebagian besar sudah memberikan asi ekslusif pada bayinya yaitu sebanyak 41 responden dan sisanya ibu tidak memberi asi ekslusif, hal itu dikarenakan orang tua yang memberikan susu formula sebagai pendamping asi karena dari awal bayi lahir air susu ibu tidak keluar dan ada beberapa bayi sebelum umur 6 bulan sudah diberi makanan pendamping asi oleh ibu nya dengan alasan bayi menangis terus karena lapar jadi diberi pisang lumat oleh ibunya, tidak hanya itu di usia 5 bulan bayi sudah diberi bubur oleh ibunya. ASI eksklusif diberikan selama 6 bulan dan disarankan sampai dengan anak berusia 2 tahun dengan pemberian makanan tambahan yang sesuai ${ }^{19}$.

\section{Pemberian MP-ASI}

Hasil dari penelitian ini menilai ketepatan orang tua dalam memberikan MP-ASI pada anaknya yang diukur melalui kesesuaian pemberian MP-ASI dengan umur, jenis dan frekuensi. Jumlah keseluruhan responden dari ketepatan pemberian MP-ASI berjumlah 35 responden. Berdasarkan usia pemberian MPASI terdapat 22 responden yang memberi MPASI sebelum usia 6 bulan. penelitian Kalsum yang menyebutkan bahwa balita yang diberi MP-ASI pertama pada usia $<6$ bulan mempunyai efek protektif terhadap kejadian gizi buruk meskipun telah dikontrol oleh kondisi perumahan, penyakit diare, pendidikan ibu, jumlah anggota keluarga, personal hygiene, inisiasi ASI dan jumlah balita ${ }^{20}$.

\section{Sanitasi dan Pelayanan Kesehatan}

1. Cuci tangan dan kebersihan alat makan

Pada penelitian ini mayoritas responden mencuci tangan dengan air mengalir saja. Waktu penting perlunya cuci tangan pakai sabun adalah sebelum makan, mengolah dan menghidangkan makanan, menyusui, memberi makan bayi/balita, sesudah buang air besar/kecil dan setelah memegang hewan/unggas ${ }^{21}$. Hasil penelitian untuk kebersihan alat makan minum balita sebagian besar responden mencuci peralatan makan dengan cara mencampur dengan piring orang dewasa dan menggunakan 2 bak air untuk pencuciannya. Tempat mencuci peralatan makan dan minum yang baik terdiri dari tiga bak pencucian yang terdiri dari bak untuk mengguyur, bak untuk menyabun dan bak untuk membilas ${ }^{22}$.

2. Akses air bersih dan Sumber air minum

Pada penelitian ini akses air bersih dan sumber air minum yang digunakan oleh responden adalah sumur. Penelitian Hidayat et al menyebutkan bahwa air yang tidak sehat akan 
mengakibatkan diare pada anak balita dan berpengaruh pada status gizinya, rendahnya akses masyarakat terhadap air bersih dan sanitasi dasar dapat meningkatkan kejadian diare pada anak balita sedangkan air minum juga harus dijaga agar tidak tercemar dari bahan-bahan berbahaya, sehingga bila air diminum tidak diragukan kemanannya dan sebaiknya air minum direbus terlebih dahulu sampai mendidih $^{23}$.

\section{Status Imunisasi}

Hasil penelitian ini menunjukkan bahwa sebagian besar anak balita sudah mendapatkan imunisasi. Penelitian Vindriana et al menyebutkan bahwa imunisasi yang lengkap mengahasilkan status gizi yang baik karena anak tidak mudah terserang penyakit yang berbahaya dan nutrisi yang dibutuhkan tubuh dapat diserap oleh tubuh dengan baik sedangkan anak yang mempunyai status imunisasi yang tidak lengkap tidak akan memiliki kekebalan tubuh sehingga mudah terserang penyakit infeksi tertentu dan anak mudah jatuh sakit dan hal ini menyebabkan turunnya berat badan pada anak sehingga anak dapat menderita gizi kurang ${ }^{24}$.

4. Pelayanan Kesehatan

Sarana pelayanan kesehatan yang sering dikunjungi oleh responden sebagian besar adalah Bidan Praktek Mandiri dengan alasan sarana tersebut lebih dekat dari rumah responden. Pelayanan kesehatan sangat berpengaruh dalam terjadinya gizi buruk pada balita. Pelayanan kesehatan dimanfaatkan oleh balita baik preventif maupun kuratif yang meliputi penimbangan, penyuluhan, kesehatan ibu dan anak, pemberian makan tambahan, suplemen gizi dan konsultasi resiko penyakit di pelayanan kesehatan ${ }^{25}$.

5. Akses Pelayanan Kesehatan

Pada penelitian ini akses pelayanan kesehatan berada dalam kategori mudah menjangkau. Akses pelayanan sangat penting untuk menunjang kesehatan masyarakat karena semakin jauh letak fasilitas kesehatan maka akan semakin turun juga derajad kesehatan masyarakat terutama pada balita, karena hal tersebut juga dipengaruhi oleh biaya transportasi untuk dapat mengakses fasilitas kesehatan ${ }^{26}$.

\section{Tingkat Konsumsi Makanan}

Konsumsi energi yang kurang dalam makanan sehari-hari dapat menyebabkan seseorang akan kekurangan gizi pada akhirnya anak yang gizinya baik lama kelamaan akan menderita gizi buruk ${ }^{27}$. Dalam penelitian ini tingkat konsumsi balita berada dalam kategori defisit tingkat berat, hal tersebut dikarenakan makanan balita kurang bervariasi selain itu ibu yang sebagian bekerja meninggalkan anak dengan keluarga terdekatnya. Menurut penelitian Diniyyah dan Nindya rendahnya tingkat konsumsi zat gizi secara terus menerus pada balita akhirnya akan meningkatkan resiko terjadinya malnutrisi ${ }^{28}$.

\section{Riwayat Penyakit Infeksi}

Pada penelitian ini terdapat 13 balita yang mengalami sakit selama 3 bulan terakhir. Gejala 
penyakit yang di derita oleh balita yaitu panas, batuk dan pilek yang mengindikasikan pada penyakit infeksi jenis ISPA. Penelitian Fransiska et al yang menyebutkan bahwa kejadian infeksi terutama ISPA lebih banyak ditemukan pada anak yang status gizinya tidak normal dibandingkan dengan anak yang status gizinya normal $^{29}$.

\section{SIMPULAN DAN SARAN}

\section{Simpulan}

Karakteristik balita BGM terdapat dalam rentang usia 12-24 bulan yang mayoritas berjenis kelamin perempuan dan sebagian besar tidak BBLR. Karakteristik keluarga sebagian besar pendapatan keluarga dibawah UMK dengan jumlah anggota keluarga $\leq 4$ orang dan mayoritas ayah bekerja sedangkan karakteristik ibu mayoritas dengan tingkat pendidikan SD/MI/SMP/MTS dengan tingkat pengetahuan cukup dan sebagian besar tidak bekerja. Pola asuh gizi sebagian besar sudah diberi kolostrum, ASI Ekslusif dan diberikam MP-ASI yang tepat sesuai dengan usia, jenis dan frekuensi pemberian MP-ASI. Sanitasi responden sebagian besar mencuci tangan hanya dengan air saja tanpa meggunakan sabun dan kebersihan alat makan mencuci memakai 2 bak saja, untuk akses air bersih dan sumber air minum mayoritas menggunakan sumur. Pelayanan kesehatan sebagian besar responden mengunjungi praktek bidan yang aksesnya mudah dijangkau dan untuk status imunisasi sebagian besar sudah lengkap. Tingkat konsumsi makanan mayoritas mengalami defisit tingkat berat dan riwayat penyakit yang di derita adalah batuk, pilek dan demam yang mengindikasikan penyakit infeksi jenis ISPA.

\section{Saran}

Saran yang diberikan adalah Dinas Kesehatan dapat bekerja sama dengan Dinas Pemberdayaan Masyarakat untuk pelatihan dan pembinaan masyarakat, Dinas pekerjaan umum pengairan dan Dinas kebersihan lingkungan hidup (DKLH) di wilayah Puskesmas Mumbulsari, serta Memantau dan mengevaluasi program kesehatan di Puskesmas terkait pola asuh seperti 1000 HPK, KADARZI, Program Baduta 2 dan Pemberian PMT secara berkala. Bagi Puskesmas dapat bekerja sama dengan Tim Penggerak Pembinaan Kesejahteraan Keluarga (TP-PKK) desa, pembekalan dan pelatihan kader terkait Program Baduta 2, Pemberian MPASI, dan PHBS.

\section{REFERENSI}

1. Departemen Kesehatan R. I. Panduan Penggunaan KMS Balita bagi Petugas Kesehatan. Jakarta : Depkes RI. 2000.

2. WHO. UNICEF-WHO-The World Bank Joint Child Malnutrition Estimates. 2012.

3. Sediaoetama, A. D. Ilmu Gizi Untuk Mahasiswa dan Profesi. Jakarta: PT. Dian Rakyat. 2012.

4. Made, A.A., Sudargo, T., Gunawan, I. M. A. Hubungan Pola Asuh dan Asupan Gizi Terhadap Status Gizi Anak Umur 6-24 Bulan di Kelurahan Mengampang, Kecamatan Barru, Kabupaten Barru. Jurnal Sains Kesehatan, 2004. 17(4). p.483-491 
5. Hasdianah, S. S., \& Peristyowati, Y. Pemanfaatan Gizi, Diet dan Obesitas. Yogyakarta : Nuha Medika. 2014.

6. Hadi, S. Jawa Timur Tempati Posisi Kedua di Indonesia Untuk Kasus Balita Gizi Buruk tahun 2015. Surabaya: Tribunnews. 2016. [Serial Online] Surabaya.tribunnews.com [15 April 2018]

7. Solichah, Z. Balita Jember di Bawah Garis Merah KMS Capai 1750 Anak. Artikel Kesehatan Antara Jatim. Jember: Antara Jatim. 2017. [Serial Online]. https://jatim.antaranews.com [6 April 2018]

8. Dinas Kesehatan Kabupaten Jember. Data Balita BGM puskesmas kabupaten jember. Jakarta: Departemen Kesehatan Republik Indonesia Bina Kesehatan Masyarakat Direktorat Bina Gizi Masyarakat. 2017.

9. Novitasari, D. Faktor-faktor Risiko Kejadian Gizi Buruk Pada Balita yang dirawat di RSUP Dr. Kariadi Semarang. Skripsi. Universitas Diponegoro Semarang: Program Pendidikan Sarjana Kedokteran. 2012.

10. Rosela, E., Hastuti, T. P., Triredjeki, H. Hubungan Status Gizi Dengan Perkembangan Anak Usia 1-5 Tahun di Kelurahan Tidar Utara Kota Magelang. Jurnal Keperawatan soedirman, 2017. 12(1). p.27-37

11. Almatsier, S. Prinsip Dasar Ilmu Gizi. Jakarta: Gramedia Pustaka Utama. 2010.

12. Pantadianan, E., Umboh, A., Warouw, S. Hubungan Status Gizi dan Berat Lahir Pada Anak Usia 2-3 Tahun. Jurnal e-Clinic, 2015. 3(1). p. 118-123

13. Damanik, M. R., Ekayanti, I., Hariyadi, D. Analisis Pengaruh Pendidikan Ibu Terhadap Status Gizi Balita di Provinsi Kalimantan Barat. Jurnal Gizi dan Pangan, 2010. 5(2). p.69-77

14. Khotimah, H., \& Kuswandi, K. Hubungan Karakteristik Ibu Dengan Status Gizi Balita Di Desa Sumur Bandung Kecamatan Cikulur Kabupaten Lebak Tahun 2013. Jurnal Obstretika Scientia, 2014. 2(1). p.146-162
15. Labada, A., Ismanto, A., Kundre, R. Hubungan Karakteristik Ibu dengan Status Gizi Balita yang Berkunjung di Puskesmas Bahu Manado. Jurnal Keperawatan, 2016. 4(1). p.1-8

16. Persulessy, V., Mursyid, A., Wijanarka, A. Tingkat Pendapatan dan Pola Makan Berhubungan dengan Status Gizi Balita dim Daerah Nelayan Distrik Jayapura Utara Kota Jayapura. Jurnal Gizi dan Dietetik Indonesia, 2013. 1(3). p.143-150

17. Nurapriyanti, I. Faktor-faktor yang Mempengaruhi Status Gizi Balita di Posyandu Kunir Putih 13 Wilayah Kerja Puskesmas Umbulharjo di Kota Yogyakarta. Skripsi. STIK Aisyiyah Yogyakarta: Program Studi Ilmu keperawatan. 2015.

18. Yafelli, D. P., \& Muqsith, A. Hubungan Riwayat Pemberian Kolostrum Dengan perkembangan Bayi Di Puskesmas Banda Sakti Kota Lhokseumawe. Jurnal Lentera, 2015. 15(13). p.12-15

19. Kementerian Kesehatan Republik Indonesia. Situasi dan Analisis ASI Eksklusif. Jakarta: Kementerian Kesehatan Republik Indonesia. 2014.

20. Kalsum, U. Hubungan Umur Pemberian Pertama Makanan Pendamping ASI (MPASI) dengan Status Gizi Anak 7-36 bulan. Jambi Medical Journal, 2015. 3(2). p. 85-99

21. Peraturan Menteri Kesehatan Republik Indonesia. Sanitasi Total Berbasis Masyarakat. Jakarta: Kementerian Kesehatan Republik Indonesia. 2014.

22. Kementerian Kesehatan Republik Indonesia. Profil Kesehatan Indonesia Tahun 2013. Jakarta: Kementerian Kesehatan Republik Indonesia. 2013.

23. Hidayat, T. S. dan Fuada, N. Hubungan Sanitasi Lingkungan, Morbiditas dan Status Gizi Balita di Indonesia. Journal of Nutrition and Food Research, 2011. 34(2). p. 104-113

24. Vindriana, V., Kadir, A., Askar, M. Hubungan Kelengkapan Imunisasi Dengan Status Gizi Pada Balita Usia 1-5 Tahun Di 
Kelurahan Watonea Wilayah Kerja Puskesmas Katobu Kabupaten Muna. Jurnal Keperawatan, 2012. 1(2). p. 177-184

25. Ma'arifat. Analisis Hubungan Pemanfaatan Pelayanan Kesehatan Dengan Status Gizi Anak Batita. Tesis. Institut Pertanian Bogor: Penelitian Program Pasca Sarjana. 2010.

26. Mufidah, N. Faktor-faktor Yang Berhubungan Dengan Status Gizi Pada Balita Di Desa Baturetno Kecamatan Banguntapan Kabupaten Bantul Tahun 2014. Skripsi. STIKES Aisyiyah Yogyakarta : Program D IV Bidan Pendidik. 2014.

27. Supariasa, I. D. N., Bakri, B., Ibnu, F. Penilaian Status Gizi. Jakarta: EGC. 2016.

28. Diniyyah, S. R., \& Nindya, T. S. Asupan Energi, Protein dan Lemak dengan Kejadian Gizi Kurang Pada Balita Usia 24-59 Bulan di Desa Suci Gresik. Jurnal Amerta Nutrition, 2017. 1(4). p. 341-350

29. Fransiska, M., Rina., Sanggara, V. O., Gustin, R. K. Hubungan Status Gizi, Status Imunisasi dan ASI Ekslusif Dengan Kejadian ISPA Pada Anak Balita. Jurnal Kesehatan STIKes Prima Nusantara Bukittinggi, 2015. 6(2). p.8-13 